\title{
The expression of E-cadherin-catenin complex in patients with advanced gastric cancer: role in formation of metastasis
}

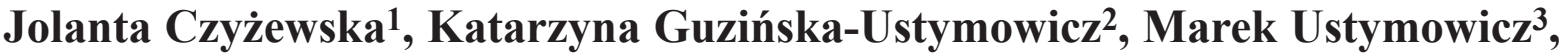 \\ Anna Pryczynicz ${ }^{2}$, Andrzej Kemona ${ }^{2}$
}

\author{
${ }^{1}$ Department of Clinical Laboratory Diagnostics, ${ }^{2}$ Department of General Pathomorphology \\ Medical University of Bialystok, Bialystok, Poland \\ ${ }^{3}$ Mechanical Department Technical University of Bialystok, Bialystok, Poland
}

\begin{abstract}
The E-cadherin-catenin complex plays an important role in the process of cell adhesion. Its dysfunction is associated with a decrease in cell differentiation and with increased invasiveness and metastasis. Our aim was to evaluate the expression of E-cadherin and B-catenin in advanced gastric cancer in relation to selected clinico-pathomorphological parameters. Formalinfixed, paraffin-embedded tissue specimens were immunohistochemically stained with monoclonal antibodies E-cadherin (NCLE-Cad, Novocastra Laboratiries Ltd; dilution 1:50), $\beta$-catenin (NCL-B-CAT, Novocastra Laboratories Ltd; dilution 1:100), $\alpha$ catenin ( $\alpha$-E-caten, Santa Cruz Biotechnology; dilution 1:300) and $\gamma$-catenin ( $\gamma$-catenin, Santa Cruz Biotechnology; dilution $1: 100)$. The expressions of E-cadherin and $\alpha-, \beta-, \gamma$-catenins in the main mass of tumor and lymph node metastasis were investigated in 91 patients with gastric cancer. No statistically significant correlation was observed between the expressions of E-cadherin, $\alpha$-, $\beta$-catenins and histological differentiation and between the expressions of E-cadherin, $\alpha$-, $\gamma$-catenins and location or depth of invasion. Moreover, the expression of $\alpha$-, $\gamma$-catenins in the main mass of tumor was not associated with lymph node metastasis. However, we found a relationship between the expression of $\beta$-catenin in the main mass of tumor and lymph node metastasis and tumor location. The depth of invasion was correlated with positive expression of $\beta$-catenin in the main mass of gastric cancer. A statistically significant association was observed between the expressions of E-cadherin and $\beta$-catenin in the main mass of tumor and lymph node involvement. The expression of $\alpha$-catenin in the main mass of tumor was also associated with histological differentiation and Lauren's classification. Statistical analysis showed an association between the expression of E-cadherin and postoperative survival time. No significant correlation was found between the expression of $\alpha$-, $\beta$-, $\gamma$-catenins and survival time. Our results may suggest that the E-cadherin-catenin complex is the factor indicative of metastasis and disease progression in gastric cancer. Also the expression of E-cadherin may play a role as a prognostic factor.
\end{abstract}

Key words: gastric cancer, E-cadherin, $\alpha$-catenin, $\beta$-catenin, $\gamma$-catenin

\section{Introduction}

Adhesion between cells and between cells and the surrounding extracellular matrix is essential in the dynamic process necessary for tissue morphogenesis and differentiation in adult organisms [1]. The specific transmembrane proteins that regulate the adhesive interactions have been identified as cadherins, integrins, selectins, the immunoglobulin superfamily, phosphatase of protein thyrosine receptor and hyaluron receptors [2].

Correspondence: J. Czyżewska Department of General Pathomorphology, Medical University of Bialystok, Waszyngtona 13 Str, PL-15-889 Bialystok, Poland; e-mail: czyzyk15@op.pl
The cadherin family divides into a few subgroups based on their tissue distribution: E-cadherin (epithelial), P-cadherin (placenta), N-cadherin (neural) and L-CAM (liver) [3-6].

Cadherins form complexes with cytoplasmic proteins - catenins which occur in three types: $\alpha-$ and $\beta$ catenins and plactoglobine ( $\gamma$-catenin) [7].

E-cadherin (E-cad), known as uvomorulin, LCAM, cell-cell $120 / 80$ or Arc-1, is present in all epithelial cells [8]. This protein plays a fundamental role in the maintenance of cellular differentiation and normal epithelial tissue architecture [9]. Its intracellular domain interacts with catenins to form the cytoplasmic cell adhesion complex (CCC). E-cadherin binds $\beta$-catenin or $\gamma$-catenin, when $\alpha$-catenin binds 
$\beta$-catenin and $\gamma$-catenin but not E-cadherin. The presence of two different complexes within the same cell results in specific binding. One complex consists of Ecadherin, $\alpha$ - and $\beta$-catenin, whereas the other contains E-cadherins and $\alpha$ - and $\gamma$-catenins [10].

Reduction in E-cadherin expression or its loss has been described in carcinomas affecting many organs, including the large intestine [11], the stomach [12], the esophagus [13], the lungs [14], or the prostate [15].

$\beta$-catenin plays two important functions. It is involved in cell adhesion, binding E-cadherin to the actin cytoskeleton via $\alpha$-catenin [16]. $\beta$-catenin is also a key element in cell signaling via the WNT/wingless pathway. It is usually "confiscated" in the process of adhesion with E-cadherin. Free $\beta$-catenin undergoes proteasomal degradation via phosphorylation by glycogen synthetase kinase $3 \beta$ (GSK-3 $\beta$ ). When the activity of GSK-3 $\beta$ is blocked by activation of the WNT pathway, $\beta$-catenin accumulates within the cytoplasm at high levels [17]. Mutations in $\beta$-catenin gene are uncommon in lung, breast or kidney carcinoma cell lines. However, it has been demonstrated that deletion in a part of the $\beta$-catenin gene in a signet ring cell carcinoma cell line is responsible for dysfunctional E-cadherin expression [18].

The $\alpha$-catenin is directly bound to the cytoplasmic domain of the cadherin. This binding is the first step in a complex connection between cadherin and the actin filament. Mutation in $\alpha$-catenin gene can be one of the mechanisms responsible for the loss of proper cell-cell adhesion [2].

$\gamma$-catenin shows strong expression in normal tissues, but not in tumors. The loss of $\gamma$-catenin expression can be due to the presence of the two cadherincatenin complexes within a cell. Moreover, $\gamma$-catenin exhibits high homology with $\beta$-catenin, which suggests that these proteins may be functionally interchangeable [2].

The E-cadherin-catenin complex plays an important role in the process of cell adhesion and partly in cell signal transduction. Its dysfunction is associated with a reduction or loss of cell and tissue differentiation and with higher invasiveness and metastasis potential. In the present study, we made an attempt to investigate the role of the E-cadherin- catenin complex in the process of metastasizing advanced gastric carcinomas.

\section{Material and methods}

Collection of samples. The study was conducted on a group of 91 patients (29 women, 62 men) with advanced gastric carcinoma treated surgically in II Department of General Surgery and Gastroenterology, Medical University of Białystok in the years 19982003.

Immunohistochemistry. Formalin-fixed, paraffin-embedded tissue specimens were cut on a microtome into $5 \mu \mathrm{m}$ thick sections, which were then deparaffinized in xylenes and hydrated in alcohol series of a decreasing concentration. In order to visualize antigen, the sections were heated in a microwave for $15 \mathrm{~min}$ in citrate buffer (pH 6.0) and incubated with $0.5 \%$ hydrogen peroxide. To block the endogenous activity of peroxidase, incubation was performed in blocking serum (Novostain Super ABC Universal Kit) for $30 \mathrm{~min}$. Next, the samples were incubated with monoclonal antibodies: E-cadherin (NCL-E-Cad, Novocastra Laboratories Ltd; dilution 1:50) - for $60 \mathrm{~min}, \beta$-catenin (NCL-B-CAT, Novocastra Laboratories Ltd) - for $60 \mathrm{~min}$; dilution 1:100, $\alpha$-cathenin ( $\alpha$-E-caten, Santa Cruz Biotechnology) - overnight at $4{ }^{\circ} \mathrm{C}$, dilution 1:300 and $\gamma$ catenin ( $\gamma$-catenin, Santa Cruz Biotechnology) - overnight at 4oC, dilution 1:100. Reaction was performed in $\mathrm{ABC}$ technique using Novostain Super ABC Universal Kit (NCL-ABCm, Novocastra Laboratories Ltd.). Color reaction for peroxidase was done with DAB chromogen (DAKO S3000, DAKO, Poland).

Evaluation of samples. Protein expression was assessed using a semi-quantitative method and defined as follows:

- High expression - when more than $30 \%$ cancer cells were Ecadherin-catenin positive

- Low expression - when there was no reaction or less than $30 \%$ of cells were E-cadherin-catenin positive.

At least 500 cancer cells in each tissue specimen were microscopically found to be E-cadherin-catenin positive $(400 \times)$.

Statistical analysis. Statistical analysis was carried out based on the $\chi^{2}$ test and Fisher's exact test. The value of $p<0.05$ was considered statistically significant. The correlation between the expressions of the proteins examined and postoperative survival was determined by Cox analysis.

\section{Results}

Statistical analysis showed no relationship between the expression of the E-cadherin-catenin complex in the main mass of tumor and gender. What is more, no relationship was also observed between E-cadherin, $\alpha-, \gamma-$ catenin and tumor location or invasion depth. Moreover, there was no correlation found between E-cadherin and $\beta-, \alpha$-catenin expression in tumor and histological differentiation grade. Also the expression of $\alpha$ - and $\gamma$ catenin was not correlated with lymph node involvement (Table 1,3$)$. However, a statistically significant correlation was revealed of $\beta$-catenin expression with tumor location $(p=0.023)$ and depth of stomach wall penetration $(p=0.027)$ (Table 1). In advanced gastric cancer the expressions of E-cadherin and $\beta$-catenin were strongly correlated with metastases to lymph nodes $(p<0.05)$ (Table 2). Tumor $\gamma$-catenin expression was found to correlate with histological differentiation grade $(\mathrm{p}=0.02)$ and with Lauren's classification $(\mathrm{p}=0.002)$ (Table 1). Moreover, there was a borderline association between $\beta$ catenin expression in the affected lymph node and tumor location $(\mathrm{p}=0.07)$ (Table 2). No correlation was revealed between the expressions of E-cadherin, $\alpha$ - and $\gamma$-catenin in the affected lymph node and the parameters studied (Table 2,4). Analysis of survival rate in patients with advanced gastric cancer showed a statistically significant correlation with E-cadherin expression in the main mass of tumor ( $p<0.05$; Fig. 1). Patients with E-cadherin-positive tumors showed a 46-month-survival after surgery as 
Table 1. Correlation between the expression of E-cadherin, $\beta$-catenin proteins and clinicopathological parameters in gastric cancer.

\begin{tabular}{|c|c|c|c|c|c|c|c|}
\hline \multirow{2}{*}{\multicolumn{2}{|c|}{ Parameters }} & \multicolumn{3}{|c|}{ L-cadherin } & \multicolumn{3}{|c|}{ B-catenin } \\
\hline & & \multirow{2}{*}{$\begin{array}{c}\begin{array}{c}\text { Low } \\
\text { expression }\end{array} \\
11(38 \%)\end{array}$} & \multirow{2}{*}{$\begin{array}{c}\text { High } \\
\text { expression }\end{array}$} & $\mathrm{p}$ & $\begin{array}{l}\text { Low } \\
\text { enxression }\end{array}$ & High & $\mathrm{p}$ \\
\hline \multirow{2}{*}{ Sex } & Female & & & \multirow{2}{*}{ NS } & $13(44.8 \%)$ & $16(55.2 \%)$ & \multirow{2}{*}{ NS } \\
\hline & Male & $26(42 \%)$ & $36(58 \%)$ & & $30(48.4 \%)$ & $32(51.6 \%)$ & \\
\hline \multirow{3}{*}{ Tumor localization } & $1 / 3$ up part & $2(33.3 \%)$ & $4(66.7 \%)$ & \multirow{3}{*}{ NS } & $6(100 \%)$ & $0(0 \%)$ & \multirow{3}{*}{0.02} \\
\hline & $1 / 3$ midlle part & $18(47.4 \%)$ & $20(52.6 \%)$ & & $18(47.4 \%)$ & $20(52.6 \%)$ & \\
\hline & $\begin{array}{l}1 / 3 \text { down part, all } \\
\text { stomach }\end{array}$ & $17(36.8 \%)$ & $30(63.2 \%)$ & & $19(40.4 \%)$ & $28(59.6 \%)$ & \\
\hline \multirow{3}{*}{ Depth of invasion } & $\begin{array}{l}\text { Mucosa, } \\
\text { submucosa }\end{array}$ & $4(33.3 \%)$ & $8(66.7 \%)$ & \multirow{3}{*}{ NS } & $2(16.7 \%)$ & $10(83.3 \%)$ & \multirow{3}{*}{0.03} \\
\hline & Muscular layer & $8(44.4 \%)$ & $10(55.6 \%)$ & & $12(66.7 \%)$ & $6(33.3 \%)$ & \\
\hline & Serosa & $25(40.3 \%)$ & $36(59.7 \%)$ & & $29(47.5 \%)$ & $32(52.5 \%)$ & \\
\hline \multirow{2}{*}{$\begin{array}{l}\text { Lauren's } \\
\text { classification }\end{array}$} & Intestinal type & $21(34.4 \%)$ & $40(65.6 \%)$ & \multirow{2}{*}{ NS } & $24(39.4 \%)$ & $37(60.6 \%)$ & \multirow{2}{*}{ NS } \\
\hline & Diffuse type & $16(53.3 \%)$ & $14(46.7 \%)$ & & $19(63.3 \%)$ & $11(36.7 \%)$ & \\
\hline \multirow{2}{*}{$\begin{array}{l}\text { Histological } \\
\text { differentiation }\end{array}$} & G2 & $17(37 \%)$ & $29(63 \%)$ & \multirow{2}{*}{ NS } & $21(45.7 \%)$ & $25(54.3 \%)$ & \multirow{2}{*}{ NS } \\
\hline & G3 & $20(44.4 \%)$ & $25(55.6 \%)$ & & $22(48.9 \%)$ & $23(51.1 \%)$ & \\
\hline \multirow{4}{*}{$\mathrm{pN}$} & 0 & $15(23.4 \%)$ & $49(76.6 \%)$ & \multirow{4}{*}{0.00000} & $24(37.5 \%)$ & $40(62.5 \%)$ & \multirow{4}{*}{0.03} \\
\hline & 1 & $11(68.8 \%)$ & $5(31.2 \%)$ & & $10(62.5 \%)$ & $6(37.5 \%)$ & \\
\hline & 2 & $10(100 \%)$ & $0(0 \%)$ & & $8(80 \%)$ & $2(20 \%)$ & \\
\hline & 3 & $1(100 \%)$ & $0(0 \%)$ & & $1(100 \%)$ & $0(0 \%)$ & \\
\hline
\end{tabular}

NS - non statistical significence

Table 2. Correlation between the expression of E-cadherin, $\beta$-catenin proteins and clinicopatholgical parameters in lymph node metastasis.

\begin{tabular}{|c|c|c|c|c|c|c|c|}
\hline \multirow{2}{*}{\multicolumn{2}{|c|}{ Parameters }} & \multicolumn{3}{|c|}{ L-cadherin } & \multicolumn{3}{|c|}{ B-calcnin } \\
\hline & & \multirow{2}{*}{$\begin{array}{c}\begin{array}{c}\text { Iow } \\
\text { expression }\end{array} \\
1(11.1 \%)\end{array}$} & \multirow{2}{*}{$\begin{array}{c}\begin{array}{c}\text { High } \\
\text { expression }\end{array} \\
8(98.9 \%)\end{array}$} & $p$ & Iow & High & $p$ \\
\hline \multirow{2}{*}{ Sex } & Female & & & \multirow{2}{*}{ NS } & $5(55.6 \%)$ & $4(44.4 \%)$ & \multirow{2}{*}{ NS } \\
\hline & Malc & $3(16.7 \%)$ & $15(83.3 \%)$ & & $6(33.3 \%)$ & $12(66.7 \%)$ & \\
\hline \multirow{3}{*}{ Tumor localization } & $1 / 3$ up part & $l(50 \%)$ & $l(50 \%)$ & \multirow{3}{*}{ NS } & $1(50 \%)$ & $1(50 \%)$ & \multirow{3}{*}{0.07} \\
\hline & 1/3 middle part & $1(8.3 \%)$ & $11(91.7 \%)$ & & $2(16.7 \%)$ & $10(83.3 \%)$ & \\
\hline & $\begin{array}{l}1 / 3 \text { donn part, all } \\
\text { stomach }\end{array}$ & $2(15.4 \%)$ & $11(84.6 \%)$ & & $8(66.7 \%)$ & $5(33.3 \%)$ & \\
\hline \multirow{3}{*}{ Depth of invasion } & $\begin{array}{l}\text { Mucosa, } \\
\text { submucosa }\end{array}$ & $0(0 \%)$ & $0(0 \%)$ & \multirow{3}{*}{ NS } & $0(0 \%)$ & $0(0 \%)$ & \multirow{3}{*}{ NS } \\
\hline & Muscular layer & $\mathrm{l}(33.3 \%)$ & $2(66.7 \%)$ & & $1(33.3 \%)$ & $2(66.7 \%)$ & \\
\hline & Scrosa & $3(12.5 \%)$ & $21(87.5 \%)$ & & $10(41.7 \%)$ & $14(58.3 \%)$ & \\
\hline \multirow{2}{*}{$\begin{array}{l}\text { Lauren's } \\
\text { classification }\end{array}$} & Intestinal type & $3(17.6 \%)$ & $14(82.4 \%)$ & \multirow{2}{*}{ NS } & $7(41.2 \%)$ & $10(58.8 \%)$ & \multirow{2}{*}{ NS } \\
\hline & Diffuse type & $1(10 \%)$ & $9(90 \%)$ & & $4(40 \%)$ & $6(60 \%)$ & \\
\hline \multirow{2}{*}{$\begin{array}{l}\text { Ilistological } \\
\text { differentiation }\end{array}$} & $\mathrm{G} 2$ & $2(16.7 \%)$ & $10(83.3 \%)$ & \multirow{2}{*}{ NS } & $5(41.7 \%)$ & $7(58.3 \%)$ & \multirow{2}{*}{ NS } \\
\hline & G3 & $2(13.3 \%)$ & $13(86.7 \%)$ & & $6(40 \%)$ & $9(60 \%)$ & \\
\hline \multirow{4}{*}{$\mathrm{pN}$} & 0 & $0(0 \%)$ & $0(0 \%)$ & \multirow{4}{*}{ NS } & $0(0 \%)$ & $0(0 \%)$ & \multirow{4}{*}{ NS } \\
\hline & 1 & $1(6.25 \%)$ & $15(93.75 \%)$ & & $6(37.5 \%)$ & $10(62.5 \%)$ & \\
\hline & 2 & $3(30 \%)$ & $7(70 \%)$ & & $5(50 \%)$ & $5(50 \%)$ & \\
\hline & 3 & $0(100 \%)$ & $1(0 \%)$ & & $0(0 \%)$ & $1(100 \%)$ & \\
\hline
\end{tabular}

NS - non statistical significence 
Table 3. Association between the expression of $\alpha$-cadherin, $\gamma$-catenin and clinicopathological parameters in main mass of gastric carcinoma.

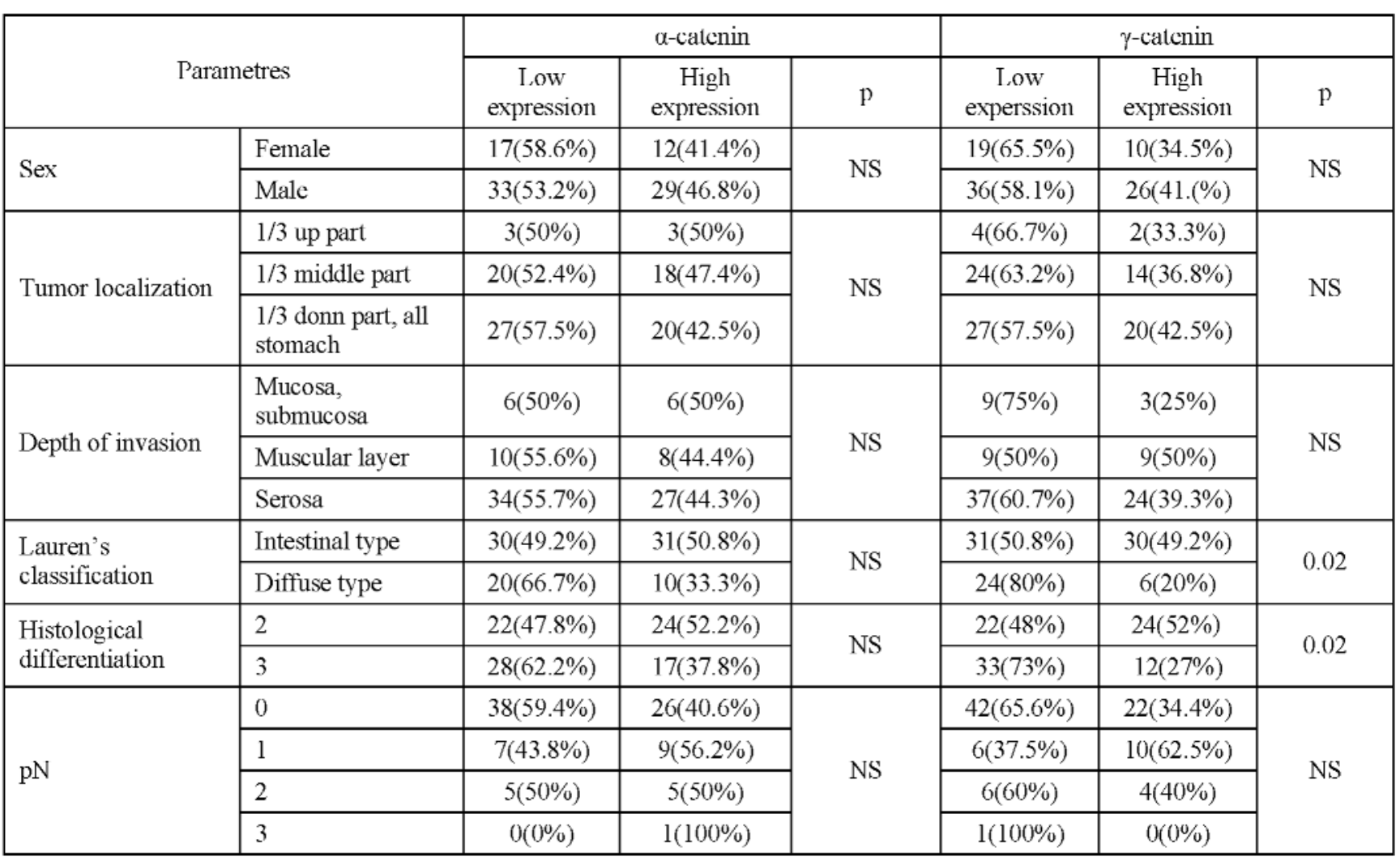

NS - non statistical significence

Table 4. Association between the expression of $\alpha$-cadherin, $\gamma$-catenin and clinicopathological parameters in lymph node metastasis.

\begin{tabular}{|c|c|c|c|c|c|c|c|}
\hline \multirow{2}{*}{\multicolumn{2}{|c|}{ Parameters }} & \multicolumn{3}{|c|}{$\alpha$-catenin } & \multicolumn{3}{|c|}{$\gamma$-catenin } \\
\hline & & \multirow{2}{*}{$\begin{array}{c}\begin{array}{c}\text { Low } \\
\text { expression }\end{array} \\
4(50 \%)\end{array}$} & \multirow{2}{*}{$\begin{array}{c}\begin{array}{c}\text { High } \\
\text { expression }\end{array} \\
4(50 \%)\end{array}$} & \multirow{3}{*}{$\frac{\mathrm{p}}{\mathrm{NS}}$} & \multirow{2}{*}{$\begin{array}{c}\begin{array}{c}\text { Low } \\
\text { experssion }\end{array} \\
5(62.5 \%)\end{array}$} & \multirow{2}{*}{$\begin{array}{c}\begin{array}{c}\text { High } \\
\text { expression }\end{array} \\
3(37.5 \%)\end{array}$} & \multirow{3}{*}{$\begin{array}{c}\mathrm{p} \\
\mathrm{NS}\end{array}$} \\
\hline Sor & Female & & & & & & \\
\hline $\mathrm{DS \lambda}$ & Male & $7(50 \%)$ & $7(50 \%)$ & & $8(53.3 \%)$ & $7(46.7 \%)$ & \\
\hline \multirow{3}{*}{ Tumor localization } & $1 / 3$ up part & $2(100 \%)$ & $0(0 \%)$ & \multirow{3}{*}{ NS } & $2(100 \%)$ & $0(0 \%)$ & \multirow{3}{*}{ NS } \\
\hline & $1 / 3$ middle part & $3(33.3 \%)$ & $6(66.7 \%)$ & & $4(40 \%)$ & $6(60 \%)$ & \\
\hline & $\begin{array}{l}1 / 3 \text { donn part, all } \\
\text { stomach }\end{array}$ & $6(54.5 \%)$ & $5(45.5 \%)$ & & $7(63.6 \%)$ & $4(36.4 \%)$ & \\
\hline \multirow{3}{*}{ Depth of invasion } & $\begin{array}{l}\text { Mucosa, } \\
\text { submucosa }\end{array}$ & $0(0 \%)$ & $0(0 \%)$ & \multirow{3}{*}{ NS } & $0(0 \%)$ & $0(0 \%)$ & \multirow{3}{*}{ NS } \\
\hline & Muscular layer & $0(0 \%)$ & $1(100 \%)$ & & $0(0 \%)$ & $1(100 \%)$ & \\
\hline & Serosa & $11(52.4 \%)$ & $10(47.6 \%)$ & & $13(59 \%)$ & $9(41 \%)$ & \\
\hline \multirow{2}{*}{$\begin{array}{l}\text { Lauren's } \\
\text { classification }\end{array}$} & Intestinal type & $5(35.7 \%)$ & $9(64.3 \%)$ & \multirow{2}{*}{0.09} & $7(50 \%)$ & $7(50 \%)$ & \multirow{2}{*}{ NS } \\
\hline & Diffuse type & $6(75 \%)$ & $2(25 \%)$ & & $6(66.7 \%)$ & $3(33.3 \%)$ & \\
\hline \multirow{2}{*}{$\begin{array}{l}\text { Histological } \\
\text { differentiation }\end{array}$} & 2 & $3(33.3 \%)$ & $6(66.7 \%)$ & \multirow{2}{*}{ NS } & $5(50 \%)$ & $5(50 \%)$ & \multirow{2}{*}{ NS } \\
\hline & 3 & $8(66.7 \%)$ & $5(33.3 \%)$ & & $8(66.7 \%)$ & $5(33.3 \%)$ & \\
\hline \multirow{4}{*}{$\mathrm{pN}$} & 0 & $0(0 \%)$ & $0(0 \%)$ & \multirow{4}{*}{ NS } & $0(0 \%)$ & $0(0 \%)$ & \multirow{4}{*}{ NS } \\
\hline & 1 & $5(33.3 \%)$ & $8(66.7 \%)$ & & $8(57 \%)$ & $6(43 \%)$ & \\
\hline & 2 & $6(66.7 \%)$ & $3(33.3 \%)$ & & $5(55.6 \%)$ & $4(44.4 \%)$ & \\
\hline & 3 & $0(0 \%)$ & $0(0 \%)$ & & $0(0 \%)$ & $0(0 \%)$ & \\
\hline
\end{tabular}

NS - non statistical significence 


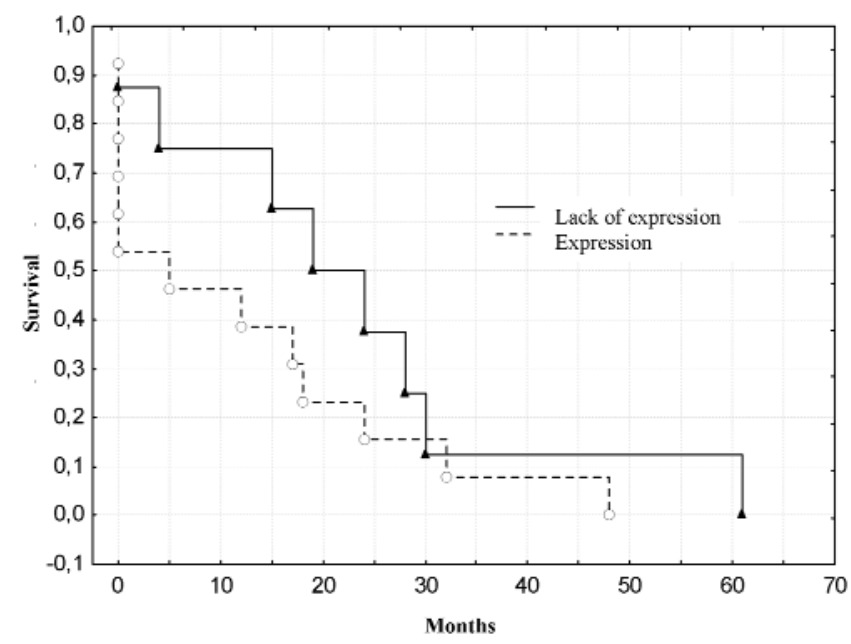

Fig. 1. Correlation of E-cadherin protein expression in main mass of tumor with survival of patients with advanced gastric cancer.

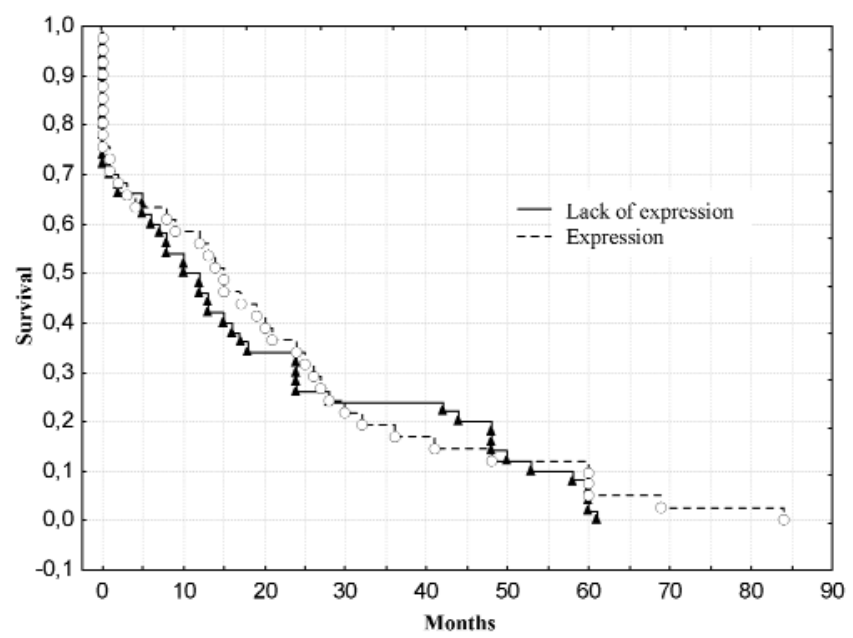

Fig. 3. Correlation of $\alpha$-catenin protein expression in main mass of tumor with survival of patients with advanced gastric cancer.

compared to 62 months observed in those without the expression. Increased mortality in patients with strong immunohistochemical reaction in tumor was noted between 5-32 months after surgery. No correlation was observed between positive staining for $\alpha-, \beta$ - and $\gamma$-catenins in the main mass of tumor and survival rate (Fig. 2, 3, 4). Patients with tumor $\alpha$ - and $\beta$-catenin expression had much longer survival (89 months) as compared to those with the expression loss (61 months). An opposite correlation was recorded in the case of $\gamma$-catenin expression: patients with positive tumor $\gamma$-catenin expression were found to survive for about 60 months after surgery as compared to those without ( 84 months).

\section{Discussion}

E-cadherin mediates adhesive interactions between epithelial cells and exerts an effect on the organization

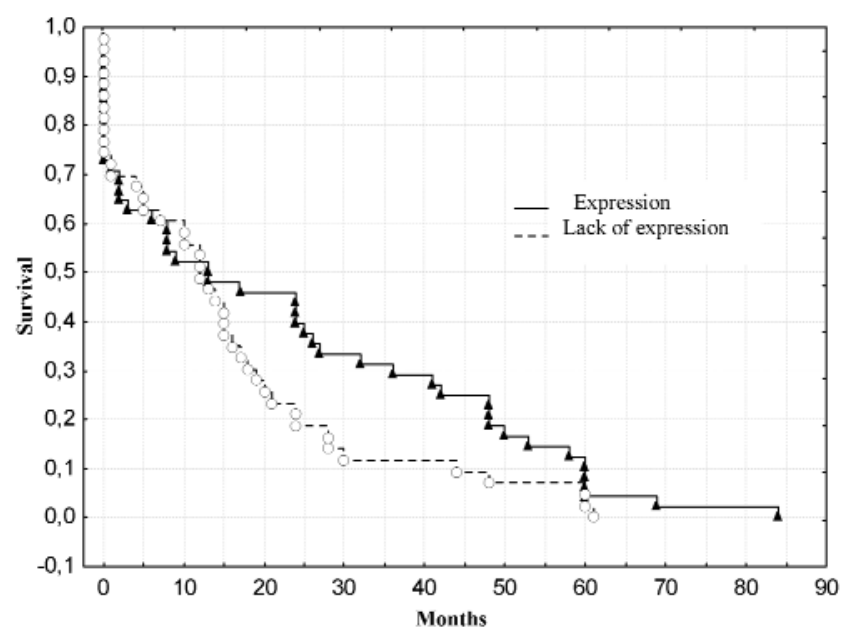

Fig. 2. Correlation of $\beta$-catenin protein expression in main mass of tumor with survival of patients with advanced gastric cancer.

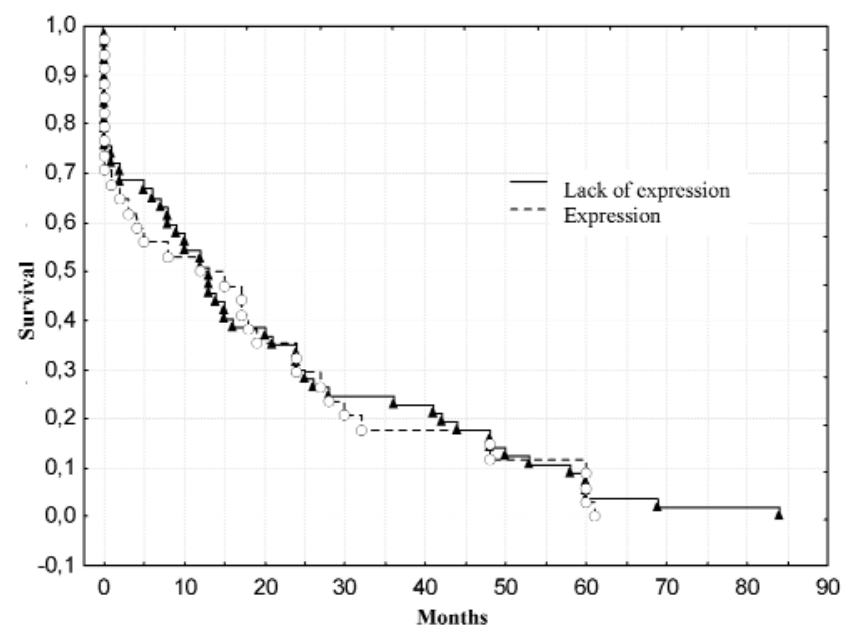

Fig. 4. Correlation of $\gamma$-catenin protein expression in main mass of tumor with survival of patients with advanced gastric cancer.

of the actin cytoskeleton through binding to catenins. E-cadherin has been defined as a suppressor gene of invasion that is frequently inhibited or undergoes mutation in invasive tumors [19]. Dysfunction of CDH1 gene (E-cadherin-coding gene) together with mutation have been found in diffuse-type gastric carcinoma [20]. Mutation in CDH1 is a genetic defect found in approximately $1 / 3$ of familial gastric cancers such as hereditary diffuse gastric cancers (HDGC) (Lu). Deletions of exon 8 or 9 , being the $\mathrm{Ca}^{2+}$ binding sites in the intracellular domain, were most common [21]. In our study, positive staining for E-cadherin was much more frequent in intestinal-type carcinomas according to Lauren's classification than in diffuse type. No statistically significant correlation was also observed between E-cadherin expression and patients' gender or histological differentiation grade. This is consistent with the results reported by Chen et al. [22], who found no correlation between E-cadherin and can- 

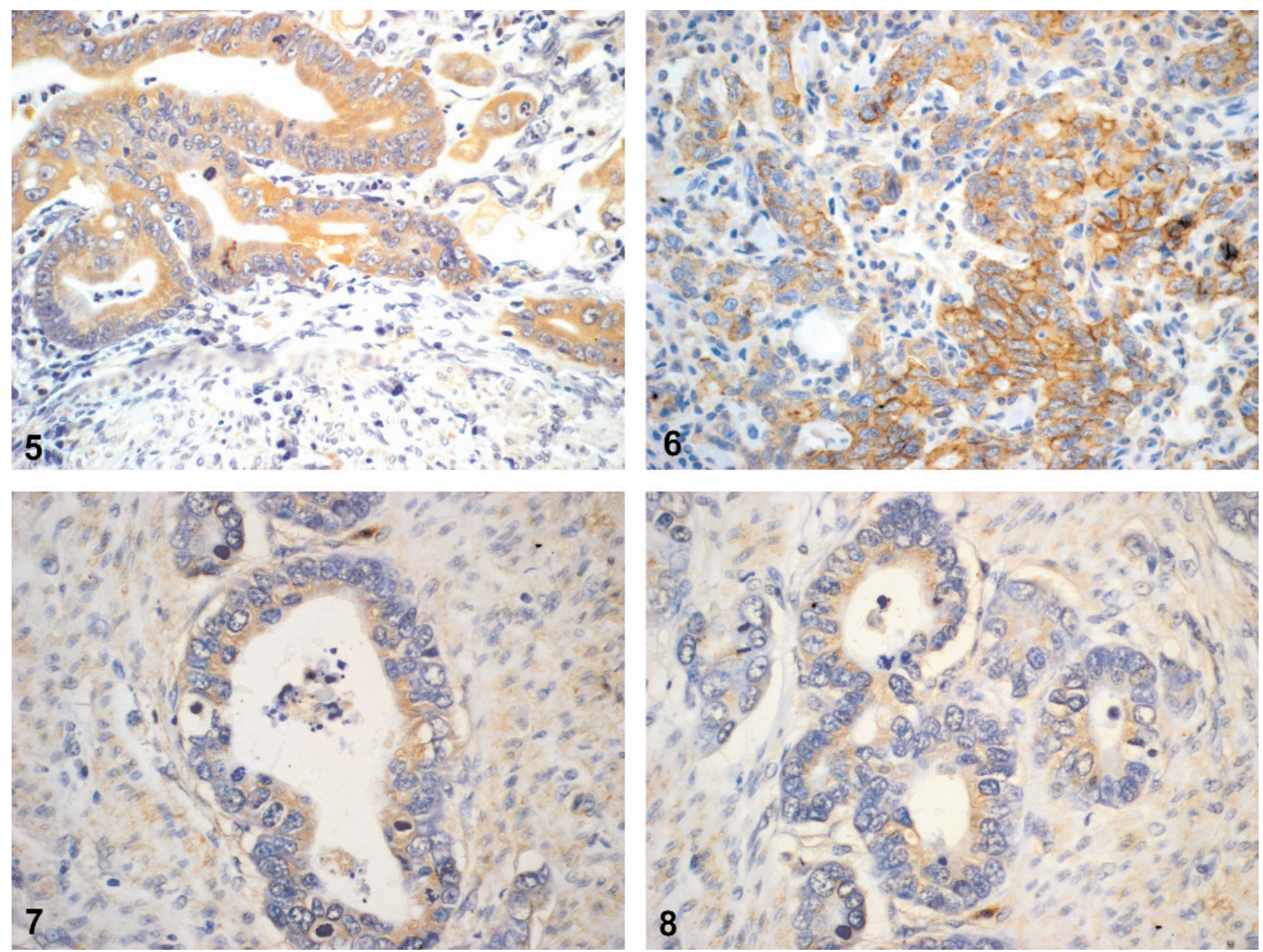

Fig. 5. Cytoplasmic cell staining pattern of E-cadherin in primary tumor. Fig. 6. Expression of $\beta$-catenin in neoplastic cells.

Fig. 7. Expression of $\alpha$-catenin protein in primary tumor. Fig. 8. Expression of $\gamma$-catenin in main mass of gastric tumor.

cer stage, vascular invasion, lymph node involvement or the presence of distant metastases. However, loss of E-cadherin expression was much more frequent in carcinomas that metastasize to distant organs than in those which do not [22]. On the other hand, Scartozzi et al. [23] observed "abnormal" E-cadherin expression more frequently in diffuse-type gastric cancer than in intestinal type according to Lauren's classification. Karayiannakis et al. [24] found a significant correlation of "abnormal" E-cadherin expression with tumor differentiation grade, location and lymph node involvement. Loss of normal E-cadherin expression can serve as a differentiation marker in gastric carcinoma [24]. Moreover, some authors suggest that the loss of "normal" E-cadherin expression can be an early stage in the carcinogenesis of the intestinal-type gastric carcinoma [25]. We observed a relationship between the loss of E-cadherin expression and lymph node involvement. Similar results were reported by Karayiannakis et al. [24], who showed that "abnormal" E-cadherin expression (loss of membrane expression) correlated with metastases to lymph nodes. Also Ohno et al. [26] reported that tumors with "abnormal" E-cadherin expression positively correlated with venous invasion and lymph node metastasis. However, other researchers described lack of correlation between "abnormal' E-cadherin expression and lymph node involvement [27]. No correlation was also found between E-cadherin expression and the lymphatic pathway of invasion or lymph node metastasis [28]. The E-cadherin-catenin complex plays a fundamental role in the development and maintenance of adhesion between epithelial cells. Changes in any of its components may lead to loss of cell adhesion and thus contribute to cancer formation [26]. Mutation in E-cadherin causes "abnormal" nuclear $\beta$-catenin location. We observed positive $\beta$-catenin expression most frequently in tumors surpassing the serosa or penetrating all over the gastric wall as compared to carcinomas invading the mucous and submucous membrane and the muscular layer. Similar results were reported by Utsunomjya et al. [31], who described $\beta$-catenin 
expression as normal or abnormal. Abnormal expression significantly correlated with diffuse-type adenocarcinoma and invasion depth. However, according to other researchers no correlation can be found between E-cadherin or $\beta$-catenin expression and the invasion depth [27]. What is more, neither nuclear nor cytoplasmatic expression was found in the deep gastric wall referred to as the invasion front [32]. This is in agreement with the finding reported by Miyazawa et al. [33] that the nuclear $\beta$-catenin expression becomes reduced in correlation with depth of invasion. Statistical analysis showed a significant relationship between $\beta$-catenin expression and lymph node metastasis. This has been confirmed in literature [27]. The expression of $\beta$-catenin was found to be closely correlated with lymph node involvement and was substantially higher when lymph node metastasis were present [34]. On the other hand, "abnormal" $\beta$-catenin expression showed no correlation with lymph node involvement [31]. We observed positive reaction for $\beta$-catenin mainly in carcinomas located in $1 / 3$ of the lower or central part of the stomach or occupying the whole organ. However, we found no correlation between $\beta$-catenin expression in the main mass of tumor and its histological differentiation according to Lauren criteria and patients' gender, which has been confirmed by other authors $[35,36]$. On the other hand, Ohno et al. [26] showed a statistically significant correlation between $\beta$-catenin expression and degree of tumor histological differentiation. A reduction in membranous $\beta$-catenin expression was associated with age, gender, tumor size or lymph node involvement, but not with histological type, tumor progression or prognosis in gastric carcinoma [36]. However, the reduction was related to low tumor differentiation grade [35]. The "abnormal" $\beta$-catenin expression closely correlated with diffusetype gastric adenocarcinoma [31]. We observed a strong, statistically significant correlation of $\gamma$-catenin expression in the main mass of tumor with Lauren's classification and histological differentiation grade. Positive staining for this protein was more common in the intestinal type at moderate grade of differentiation (G2). The other clinicopathological parameters did not correlate with $\gamma$-catenin expression. Moreover, we found no relationship between any of the parameters examined and tumor $\alpha$-catenin expression. This is not consistent with the findings reported by Joo et al. [37], who observed reduced expressions of E-cadherin, $\alpha$-, $\beta$ - and $\gamma$-catenin much more frequently in diffuserather than intestinal-type early carcinoma according to Lauren's classification. A reduction in the expression of the E-cadherin-catenin complex correlated with low differentiation grade but not with age, gender, tumor size, location, macroscopic type, depth of invasion or lymph node involvement. This seems to indicate that dysfunction of the E-cadherin-catenin com- plex in the early stage of carcinogenesis plays a critical role in damaging tissue architecture and differentiation in early gastric carcinomas [37]. The E-cadherincatenin complex may have an important role in the genesis of histological differentiation and may serve as a marker of gastric carcinoma differentiation [38]. The complex plays a key part in the intercellular adhesion of epithelial cells. Abnormal expression (cytoplasmic) and function of its respective components are involved in tumor progression and metastasis. A significant relationship has been revealed between the expression of E-cadherin and $\beta$-catenin with histological type and differentiation grade of gastric carcinoma. Moreover, a correlation has been found between the expression of $\gamma$-catenin and histological type [39]. Abnormal expression of the E-cadherin-catenin complex may affect tumor growth type. Song et al. [40] showed a relationship between the complex expression and tumor growth inhibition in the stomach. The change in the complex expression from membranous to cytoplasmic seems to affect the macroscopic pattern of tumor growth, similarly to Lauren's classification, stage of advancement or size [40]. In our study, positive staining for the E-cadherin-catenin complex proteins was more frequent in the intestinal type tumors. However, Shun et al. [41] observed the expression of E-cadherin, $\alpha$ - and $\gamma$-catenin in diffuse type tumors according to Lauren's classification. Moreover, they found higher frequency of abnormal E-cadherin expression and lower frequency of abnormal $\beta$-catenin level in patients with lymph node involvement [41]. In our study, the survival rate in patients with advanced gastric carcinoma showed a statistically significant correlation with E-cadherin expression in the main mass of tumor. In E-cadherin positive patients, survival rate was significantly lower as compared to those without the expression, which suggests that positive staining for this protein in tumor is an unfavorable prognostic factor. We observed similar correlation between $\gamma$-catenin expression in the main mass of tumor and survival rate. These data, however, were not statistically significant. We also demonstrated that the survival time in patients with tumor $\alpha$ - and $\beta$-catenin expression was much longer as compared to those without. The results may indicate a prognostically beneficial role of $\alpha$ - and $\beta$-catenin in patients with advanced gastric carcinomas. The data, however, were not statistically significant. Ramesh et al. [35] revealed a relationship between the reduction in $\beta$ catenin expression and low differentiation grade of gastric cancers and shorter survival, but not between E-cadherin or $\alpha$-catenin expression and survival. The results suggest that reduced membranous $\beta$-catenin expression may implicate unfavorable prognosis in gastric carcinoma. The expression of $\beta$-catenin, like invasion depth and lymph node involvement, was an 
independent prognostic factor associated with shorter survival time after surgery [31]. Longer postoperative survival was noted for carcinomas in which membranous $\beta$-catenin expression was maintained irrespective of carcinoma type, differentiation grade or advancement stage. Patients with unchanged normal membranous staining for E-cadherin and $\beta$-catenin were found to survive $3-5 \times$ longer than those with its loss [43]. Thus, the loss of membranous staining for E-cadherin and $\beta$-catenin in patients with gastric carcinoma is associated with poor prognosis [2, 38]. Liu et al. [44] observed that the 5-year-survival rate in patients with lymph node metastases and with adhesion molecule expression (cad-cat complex) was significantly lower as compared to those with metastasis and absent complex protein expression. A comparison of the expression pattern between the main mass of tumor and the affected lymph node can provide new information for patients with advanced gastric carcinoma [44]. Summing up, our findings indicate a relationship between the expression of the E-cadherin- $\beta$-catenin complex and lymph node involvement in advanced gastric carcinomas. Moreover, we observed a correlation between the expression of $\alpha$-, $\beta$-catenin and such invasion factors as tumor differentiation grade or Lauren's classification. We also demonstrated that the E-cadherin expression can be an unfavorable prognostic factor for patients with gastric carcinoma.

\section{References}

[ 1] Pignatelli M. Integrins, cadherins and catenins: molecular cross-talk in cancer cells. $J$ Pathol. 1998;186:1-2.

[2] Ramburan A, Govender D. Cadherins and catenins in pathology. Curr Diag Pathol. 2002;8:305-317.

[ 3] Nagafuchi A, Shirayoshi Y, Okazaki M, Yasuda M. Transformation of cell adhesion properties by exogenously introduced E-cadherin cDNA. Nature. 1987;329:341-343.

[4] Hatta K, Takeichi M. Expression of N- cadherin adhesion molecules associated with early morphogenetic events in chick development. Nature. 1986;20:447-449.

[5] Nose A, Nagafuchi A, Takeichi M. Isolation of placental cadherin cDNA: identification of a novel family of cell- cell adhesion molecules. Eur Mol Biol Org. 1987;6:3655-3661.

[6] Gallin WJ, Sorkin BC, Edelman GM, Cunningham BA. Seqeence analysis of cDNA clone encoding the liver cell adhesion molecule, L-CAM Proc Natl Acad Sci USA. 1987;84:2808-2812.

[7] Ozawa M, Baribault H, Kelmer R. The cytoplasmic domain of the cell adhesion molecule uvomorulin associates with three independent proteins structurally related in different species. EMBO J. 1989;8:1711-1717.

[8] Wijnhoven BPL, Dinjens WNM, Pignatelli M. E-cadherincatenin cell- cell adhesion complex and human cancer. Br J Surg. 2000;87:992-1005.

[9] Moriyama N, Ishihara S, Hirose M, Watanabe S, Sato N, Kinoshita Y. E-cadherin is essential for gastric epithelial restitution in vitro: a study using the normal rat gastric mucosal cell line RGM1. J Lab Clin Med. 2001;138:236-242.

[10] Hinck L, Näthke IS, Papkoff J, Nelson WJ. Dynamics of cadherin/ catenin complex formation: novel protein interactions and pathaways of complex assembly. J Cell Biol. 1994;125: $1327-1340$.

[11] Van Aken J, Cuvelier CA, De Weaver N, Roles J, Gao Y, Mareel MM. Immunohistochemical analysis of E-cadherin expression in human colorectal tumors. Pathol Res Pract. 1993;189:975-978.

[12] Ohno T, Aihara R, Kamiyama Y, Mochiki E, asao T, Kuwano H. Prognostic significance of combinated expression of MUC1 and adhesion molecules in advanced gastric cancer. Eur J Cancer. 2006;42: 256-263.

[13] Bongiorno PF, al-Kasspooles M, Lee SW, Rachwal WJ, Moore JH, Whyte RI, Orringer MB, Beer DG. E-cadherin expression in primary and metastatic thoracic neoplasmas and in Barrett's oesophagus. Br J Cancer. 1995;71:166-172.

[14] Bohm M, Totzeck B, Brichmeier W, Wieland I. Differences of E-cadherin expression levels and patterns of primary human lung cancer. Clin Exp Metastasis. 1994;12:55-62.

[15] Morton RA, Ewing CM, Nagafuchi A, Tsukita S, Isaacs WB. Reduction of E-cadherin levels and deletion of the Ralphacatenin gene in human prostate cancer cells. Cancer Res. 1993;53:3585-3590.

[16] Jung A, Schrauder M, Oswald U, Knoll C, Sellberg P, Palmqvist R, Niedobitek G, Brabletz T, Kirchner T. The invasion front of human colorectal ademocarcinomas showns colocalization of nuclear $\beta$ - catenin, cyclin D1 and p16 INK4A and is a region of low proliferation. Am J Pathol. 2001;159: 1613-1617.

[17] Polakis. Wnt signaling and cancer. Genes Dev. 2000;14: 1837-1851.

[18] Oyama T, Kanai Y, Ochiai A, Akimoto S, Oda T, Yanagihama N, Nagafuchi A, Tsukita S, Shibamoto S, Ito F et el. A truncated beta- catenin disrupts the interaction between E-cadherin and alphacatenin: a cause of loss of intracellular adhesiveness in human cancer cell lines. Cancer Res. 1994;54: 6282-6287.

[19] Hirohashi S. Inactivation of the E-cadherin- mediated cell adhesion system in human cancars. Am J Pathol. 1998;153: 333-339.

[20] Lu Y, Xu Y-Ch, Shen J, Yu R-B, Niu J-Y, Guo J-T, Hu X, Shen $\mathrm{H}-\mathrm{B}$. E-cadherin gene C-160A promoter polymorphism and risk of non-cardia gastric cancer in a Chinese population. World J Gastroenterol. 2005;11: 56-60.

[21] Lus RG, Calvo MC, Lopez LG, Cancer RC, Molina AM, Sanchez ED, Parilla AC. Treatment of cefazolin in 45 cases of urinary tract infections. Chemotherapy. 1977;23:106-113.

[22] Chen H-Ch, Chu RY, Hsu P-N, Hsu P-I, Lu J-Y, Lai K-H, Tseng H-H, Chou N-H, Huang M-S, Tseng Ch-J, Hsiao M. Loss of E-cadherin expression correlates with poor differentiation and invasion into adjacent organs in gastric adenocarcinomas. Cancer Letters. 2003;201:97-106.

[23] Scartozzi M, Galizia E, Freddari F, Berardi R, Cellerino R, Cascinu S. Molecular biology of sporadic gastric cancer: prognostic indicators and novel therapeutic approaches. Cancer Treat Rev. 2004;30:451-459.

[24] Karayiannakis AJ, Syrigos KN, Chatzigianni E, Papanikolaou S, Karatzas G. E-cadherin expression as a differentiation marker in gastric cancer. Hepatogastroenterology. 1998; 45: 2437-2442.

[25] Mingchao, Devereux TR, Stockton P, Sun K, Sills RC, Clayton N, Portier M, Flake G. Loss of E-cadherin expression in gastric intestinal metaplasia and later stage p53 altered expression in gastric carcinogenesis. Exp Toxicol Pathol. 2001;53:237-246.

[26] Ohno T, Aihara R, Kamiyama Y, Mochiki E, Asao T, Kuwano $\mathrm{H}$. Prognostic significance of combined expression of MUC1 and adhesion molecules in advanced gastric cancer. Eur $J$ Cancer. 2006;42:256-263. 
[27] Zhou Y-N, Xu C-P, Han B, Li M, Qiao L, Fang D-Ch, yang $\mathrm{J}-\mathrm{M}$. Expression of E-cadherin and $\beta$ - catenin in gastric carcinoma and its correlation with the clinicpathological features and patent survival. World $J$ Gastroenterol. 2002;8:987-993.

[28] Mayer B, Johnson JP, Leitl F, Jauch F, Heiss KW, Schildberg FW, Brichmeier W, Funke I. E- cadsherin expression in primary and metastatic gastric cancer: down- regulation correlates with cellular dedifferentiation and glandular disintegration. Cancer Res. 1993;53:1690-1695.

[29] Ma M, Devereux TR, Stockton P, Sun K, Sills RC, Clayton N, Portier M, Flake G. Los sof E-cadherin expression in gastric intestinal metaplasia and later stage p53 altered expression in gastric carcinogenesis. Exp Toxic Pathol. 2001;53:237-246.

[30] Fricke E, Keller G, Becker I, Schott Ch, Plaschke S, Rudelius M, Hermannstädter $\mathrm{Ch}$, Busch R, Höfler H, Becker K-F, Luber B. Relationship between E cadherin gene mutation and p53 gene mutation, p53 accumulation, Bcl-2 expression and Ki-67 staining in diffuse- type gastric carcinoma. Int $J$ Cancer. 2003;104:60-65.

[31] Utsunomija T, Doki Y, Takemoto H, Shiozaki H, Yano M, Inoue M, Yasuda T, Furjiwara Y, Monden M. Cilnical significance of disordered beta- catenin expression pattern in human gastric cancers. Gastric Cancer. 2000;3:193-201.

[32] Tsukashita S, Kushima R, Bamba M, Nakamura E, Mukaisho $\mathrm{K}$, Sugihara H, Hattori T. Beta- catenin expression in intramucosal neoplastic lesions of the stomach. Oncology. 2003;64:251-258.

[33] Miyazawa K, Iwaya K, Kuroda M, Harada M, Serizawa H, Koyanagi Y, Sato Y, Mizokami Y, Matsuoka T, Mukai K. Nuclear accumulation of beta- catenin in intestinal- type gastric carcinoma: correlation with early tumor invasion. Virchows Arch. 2000;437:508-513.

[34] Obana S, Uda H, Kuwabara H, Sakamoto H. Two types of lymphatic invasion in lymph node metastasis with special references to the morphology of gastric carcinomas and immunohistology of E-cadherin and $\beta$-catenin. Kobe $J$ Med Sci. 2002;48:43-54.

[35] Ramesh S, Nash J, McCulloch PG. Reduction in membranous expression of beta- catenin and increased cytoplasmic E-cadherin expression predict poor survival in gastric cancer. $\mathrm{Br} J$ Cancer. 1999;81:1392-1397.
[36] Grabasch H, Takeno S, Noguchi T, Hommel G, Gabbert HE, Mueller W. Different patterns of beta- catenin expression in gastric carcinoma: relationship with clinicopathological parameters and prognostic outcome. Histopathology. 2001; 39:141-149.

[37] Joo YE, Rew JS, Choi SK, Bom HS, Park CS, Kim SJ. Expression of E-cadherin and $\beta$-catenins in Elary gastric cancer. J Clin Gastroenterol. 2002;35:35-42.

[38] Chan AO, Lam SK, Chu KM, Lam CM, Kwok E, Leung SY, Yuen ST, Law SY, Hui WM, Lai KC, Wong CY, Hu HC, Lai $\mathrm{CL}$, Wong J. Soluble E-cadherin is a valid prognostic marker in gastric carcinoma. Gut. 2001;48:808-811.

[39] Karatzas G, Karayiannakis AJ, Syrigos KN, Chatzigianni E, Papanikolaou S, Simatos G, Papanikolaou D, Bogris S. Expression patterns of E-cadherin-catenin cell-cell complex in gastric cancer. Hepatogastroenterology. 2000;47:14651469.

[40] Song SY, Kim S, Kimm DS, Son HJ, Rhee JC, Kim YL. Abnormal expression of E-cadherin in early gastric carcinoma: its relationship with macroscopic growth patterns and catenin alpha and beta. J Clin Gastroenterol. 2004;38:252259.

[41] Shun CT, Wu MS, Lin MT, Chang MC, Lin JT, Chuang SM. Immunohistochemical evaluation of cadherin and catenin expression in early gastric carcinomas: correlation with clinicopathologic characteristics and Helicobacter pylori infection. Oncology. 2001;60:339-345.

[42] Joo YE, Rew JS, Kim HS, Choi SH, Park CS, Kim SJ. Changes in the E-cadherin-catenin complex expression in early and advanced gastric cancers. Digestion. 2001;64:111119.

[43] Jawhari A, Jordan S, Poole S, Browne P, Pignatelli M, Farthing MJA. Abnormal immunoreactivity of the E-cadherin- catenin complex in gastric carcinoma: relationship with patient survival. Gastroenterology. 1997;12:46-54.

[44] Liu J, Ikeguchi M, Nakamura S, Kaibara N. Re- experssion of the cadherin- catenin complex in lymph nodes with metastasis in advanced gastric cancer: the relationship with patent survival. J Exp Clin Cancer Res. 2002;21:65-71.

Submitted: 16 August, 2009 Accepted after reviews: 24 October, 2009 